\title{
IMPROVED INTERPERSONAL INTELLIGENCE MODEL STUDENTS THROUGH COOPERATIVE LEARNING (TYPE two stay two stray) IN LEARNING IPS (Classroom Action Research in Class VIII C SMP Negeri 45 Bandung)
}

\author{
Kania Dewi *, \\ kaniaadewi3011@gmail.com \\ Study Program of Social Sciences
}

\author{
Dadang Sundawa, \\ Asep Mulyadi
}

\begin{abstract}
This research is supported by low interpersonal intelligence of learners on IPS learning in class VIII C SMP Negeri 45 Bandung. This can be seen from the still low empathy, prosocial, low self-awareness as a member of the group, social ethics of learners, problem-solving skills and effective communication skills of learners. Seeing the problem, the researcher chose Cooperative Learning Model Type Two Stay Two Stray (TSTS) as a solution to improve students' interpersonal intelligence. The purpose of this study is to describe the planning, implementation, obstacles and solutions and increase interpersonal intelligence. The type of research used is Class Action Research (PTK) Kemmis and Mc model. Taggart which consists of four stages. Stages of planning in this study include determining SK / KD and teaching materials, preparing RPP, Student Worksheet and create research instruments according to the needs of researchers. This research was conducted in three cycles and obtained the result of improvement of students' interpersonal intelligence in IPS learning. Increased interpersonal intelligence of learners is characterized by an increase that occurs in every aspect of the assessment of interpersonal intelligence. This proves cooperative learning model type two stay two stray (TSTS) can improve students' interpersonal intelligence.
\end{abstract}

Keywords: Interpersonal Intelligence, Cooperative Learning Model type Two Stay Two Stray (TSTS).

*main author

\section{INTRODUCTION}

Education is a means to create superior human resources. Through education is expected to produce human beings who have the ability to be able to realize the goals of national development. According to Redja Mudyahardjo, 2001 (in Sagala, 2011 pp 3), Education is all learning experience that takes place in all environments and throughout life. Furthermore, Jhon Dewey (in Sagala, 2011 pp 3) also suggests an education is a basic process, either power, or intellectual power, or emotional power or feeling directed towards human nature and to each other. In the implementation of education to improve and develop the existing points in a person or learners. This is in line with the Law of National Education System no. 20 The year 2003 article 1 paragraph 1 which states:

Education is a conscious and well-planned effort to create an atmosphere of learning actively developing its potential to have spiritual power, self-loathing, personality, intelligence, noble character, and skills it needs, society, nation, and state.
Based on the definition of education above can be seen an education is an important thing for learners to be able to develop and channel the potential that is in him. In addition, education clearly has a very important goal is to prepare learners who are able to play a role in terms of society, nation and state are also capable adjust to the best possible with its environment will cause changes in the students themselves so that it can function in accordance with its competence in public life.

In the implementation of education, of course, cannot be separated from the learning and learning process. Where learning and learning process is a major part of the implementation of education. According to Gagne (1977) (in Komalasari 2013 p. 2) defines learning as a process of behavioral change that includes changes in human tendencies such as attitudes, interests, or values and changes in their ability to increase the ability to perform different types of performance. While learning can be defined as a system or process of teaching subjects or learners who planned or designed, implemented, and evaluated systematically so that students or learners can achieve the goals of learning effectively and efficiently (Komalasari, 2013 pp 3). Furthermore, according to Corey (1986) in (Sagala, 2011 p. 61) suggests the concept of learning as a process whereby one's environment is deliberately managed to enable him to participate in certain behaviors under specific conditions or generate responses to specific situations.

IPS is one of the subjects that not only learn about the theoretical and rote concept. In accordance with its nature, IPS is a subject that studies various life systems that include human behavior, including the social problems that are in it. Furthermore, Puskur (2006) in (Rizki, 2016 pp. 24) discloses the learning objectives of social studies themselves, that is to develop the potential of learners to be sensitive to social problems that occur in society, have a positive mental attitude towards an improvement of all inequities that occur, and skilled overcoming every problem that happens everyday. In this case, to realize the purpose of learning IPS is needed interpersonal intelligence in the students, namely the ability to sensitive to social problems, the ability to solve social problems and positive attitudes toward an improvement of all inequities that occur, as well as communication skills in interpersonal relationships in the community. 
Based on the observations conducted in class VIII-C SMP Negeri 45 Bandung, researchers see that during the learning process IPS learners have less interpersonal intelligence. The low interpersonal intelligence of learners is very visible during the learning process, including; First, there is still a lack of respect for the students themselves, this is seen when the learning process of many learners who do not pay attention and listen well what is being conveyed by the teacher, in addition to the question and answer activities of many learners who do not pay attention and listen to opinions her friend. Even many learners who tend to show expression that is not good when other friends are expressing opinions. Second, learners less able to build good relationships with other learners, this is apparent when the discussion group division, many learners who do not want to join with a group of friends who have been determined at random by the teacher. Learners prefer to group with their close friends or friends one gang. In addition, learners are also difficult to build cooperation, it is seen when the discussion activities of many learners are silent and rely on his friends to do the task that has been given by the teacher. Third, learners lack self-awareness of their role in the group, it is seen when the discussion process took place many learners who are less responsible for the task by relying on his friends to do the task given by the teacher. Fourth, learners lack social ethics, it is seen when the learning process takes place where there are some students who mock each other and say harsh words. Fifth, learners less able to build effective communication among learners, it is seen when the presentation activity, where some groups of learners cannot answer questions given by other groups due to lack of good communication among group members.

Lack of development of interpersonal intelligence of learners is also seen in the process of teaching and learning in the classroom. Based on the observation of the researcher, it is seen that in teaching and learning activities, students are given less opportunity to build; attitudes of empathy, the attitude of prosocial learners or the ability of social relationships learners, cooperation, a social sensitivity of learners and good communication skills among learners. Teachers are more focused on the delivery of teaching materials and cognitive abilities of learners only. In this case, learning is more emphasized on understanding the concept and less developing other aspects such as values, attitudes, and social behavior, so that less learning process can hone the intelligence of interpersonal learners. Though learning IPS not only focus on the delivery of teaching materials and understanding of the concept alone.

Interpersonal intelligence is one of the intelligence needed by learners as an individual in building relationships and social communication in the environment. According to Gardner (1993) in (Armstrong, 2013 pp 7) interpersonal intelligence is the ability to understand and make differences in mood, purpose, motivation, and feelings toward others. This can include sensitivity to facial expressions, voice, and gestures; the ability to distinguish between different types of interpersonal cues, and the ability to respond effectively to these cues in some pragmatic way (Armstrong, 2013, pp. 7). In line with that opinion Uno (2010 p.55) mentions that interpersonal intelligence is the ability to work effectively with others, empathize and understand and appreciate the motivation. In this case, interpersonal intelligence can help learners to establish good relationships among learners, cooperation, good communication among learners and foster the motivation of learners as learners.

Interpersonal intelligence is required by learners to come up with ideas from others or throw ideas into others so they can learn effectively. These social learners benefit most from group learning (Uno, 2010 p. 145). In addition, with high interpersonal intelligence learners as individuals will be able to empathize well, interact and develop a harmonious relationship and able to establish effective communication with others (Rizki, 2016 pp 2).

Based on the above exposure and the focus of the problem of low interpersonal intelligence of these learners is a problem that should get proper attention and handling. In overcoming these problems, of course, the role of teachers is needed in the learning process. To overcome these problems can be done by applying the method of learning that can encourage learners to develop empathy, prosocial, self-awareness, social ethics, problem-solving skills and effective communication among learners so expected to improve students' interpersonal intelligence. Learning model that is considered able to improve students' interpersonal intelligence is Cooperative Learning type learning model Two Stay Two Stray (TSTS). According to Roger, et al (1992) in (Huda, 2011 pp. 29) cooperative learning model or cooperative learning model is a group learning learning activity organized by a principle that learning should be based on a social change of information among learners groups in which each learner is responsible for his own learning and is encouraged to enhance the learning of the other members. This learning model is considered suitable because in the learning process is not only emphasized on the understanding of concepts or subject matter, but learners in demand to work together and build good communication among learners.

Departing from the description of the above background, the authors are interested to examine efforts to improve students' interpersonal intelligence. Through the application of Cooperative Learning model type Two Stay Two Stray is expected to improve students' interpersonal intelligence. Therefore, it is not easy to get the job done. "Improvement of Interpersonal Intelligence Students Through Learning Cooperative Learning Type Two Stay Two Stray (TSTS) Model On social studies Learning (Classroom Action Research In Class VIII C SMP Negeri 45 Bandung)".

The problem formulation of this research is first, to plan cooperative learning model type two stay two stray (TSTS) to improve the interpersonal intelligence of learners in class VIII C SMP Negeri 45 Bandung. Second, implement cooperative learning model type two stay two stray (TSTS) to improve students' interpersonal intelligence on learning social studies in class VIII C SMP Negeri 45 Bandung. Third, the obstacles and solutions in the implementation of cooperative learning model type two stay two stray (TSTS) to improve the interpersonal intelligence of learners in class VIII C SMP Negeri 45 Bandung, Fourth, improvement of interpersonal intelligence of learners after the implementation of cooperative learning model type two stay two stray (TSTS) on 


\section{METHODS}

This research was conducted at SMP Negeri 45 Bandung, located at Jl. Yogyakarta No. 01 Bandung. The subject of this research is the students of class VIII-C with the number of students 40 people. The research method used in this research is Classroom Action Research method (PTK). According to Rochman Natawijaya (1997) in (Muslich, 2009 p. 9) reveals that Classroom Action Research (PTK) is an examination of situational and contextual practical issues aimed at determining appropriate action in the framework of problemsolving.
The research design used in this research is Kemmis and Mc Taggart model consisting of four stages, namely implementation planning, observation, and reflection. The design of this study was conducted in several cycles until the results of the data obtained became saturated. For more details below presented a chart on the design of PTK model Kemmis and Mc. Taggart as follows:
Model Kemmis and Mc. Taggart

The research instruments used are observation guides, field notes, interview guides, and documentation. So the technique of data collection is observation, interview, and documentation study. While for qualitative data analysis techniques such as data reduction, data display and take conclusions or verification. The data validation using the Hopkins model as quoted Wiriatmaja, 2005, p. 168-171) including member check, triangulation, saturation, audit trail and expert opinion.

\section{RESULTS AND DISCUSSION}

The results of this study refer to the formulation of the problems contained in the introductory chapter. The formulation of this problem includes four things: how to plan learning with cooperative learning type two stay two stray model (TSTS) to improve students' interpersonal intelligence on IPS learning, how to implement cooperative learning model type two stay two stray (TSTS) to improve participants interpersonal intelligence educate on IPS learning, how the obstacles and solutions in the implementation of cooperative learning model type two stay two stray (TSTS) to improve students' interpersonal intelligence on learning social studies,

\section{Adopted from Wiriaatmadja (2014, p. 66)}

and how to increase the interpersonal intelligence of learners after the implementation of cooperative learning model type two stay two stray TSTS) on IPS learning.

First, the planning done by the researcher is by choosing the basic competence, determining the subject matter and theme, the learning method, the instructional media, preparing the name tag, preparing the observation sheet, making the Lesson Plan (RPP), and determining the division of each observer's task. Planning is done in every cycle.

Second, the implementation of the cycle is done with two actions. In the first cycle, the teacher's first action explains first the material will be learned by the learner. Then the teacher divides the learner into 10 groups at random consisting of four learners in each group. Although many students protest because they want to choose their own group and do not want to group with friends who do not learners like. The division of the group is still done randomly by way of numerical learners. The next teacher divides the different themes in each group. At the first meeting of the second act, the teacher asks the learners to sit down with their group members and learners 
sharing the role of guest and reception. Furthermore, the teacher explains the steps of the learning model to be used in which two learners who act as guests will go around visiting other groups to record and get information from other groups about the theme they discuss. While the role of a receptionist duty to explain to guests what things the group knows and discuss. The teacher gives visitors time and receives guests for three minutes to visit once and receive guests. After the completion of the visit, the teacher asks the students to sit back together with their group and give them five minutes to discuss and distribute the student worksheets to be done in groups and appoint some representatives from the group to present their group discussion results. After the activity is completed then the teacher conducts a question and answer session and concludes with the learners on a course that has been studied.

The second cycle, the implementation of the action is almost the same as the first cycle. But there are some differences with the previous cycle that is the second cycle of learners who act as guests are given a student worksheet to record important points of what is described by other groups. At the second meeting, the learners have to understand the topic that the group is discussing so it is not allowed to read back his notes while giving information to his friend (receptionist). In addition to this second cycle of the group that first completed the worksheet, the group can first present the results of the discussion.

The third cycle, the implementation of the action is almost the same as the previous cycle. This third cycle before the teacher explains the teaching materials the teacher provides guidance in the form of rules that must be obeyed by the learners during the learning process. After the student worksheet has finished the teacher shuffle the draw to determine the representative of the group who will present the results of the group discussion in front of the class. After that, the teacher conducted a question and answer session and concluded the learning outcomes with the learners.

\section{Diagram 1 Persentase Kecerdasan Interpersonal Peserta Didik Setiap}

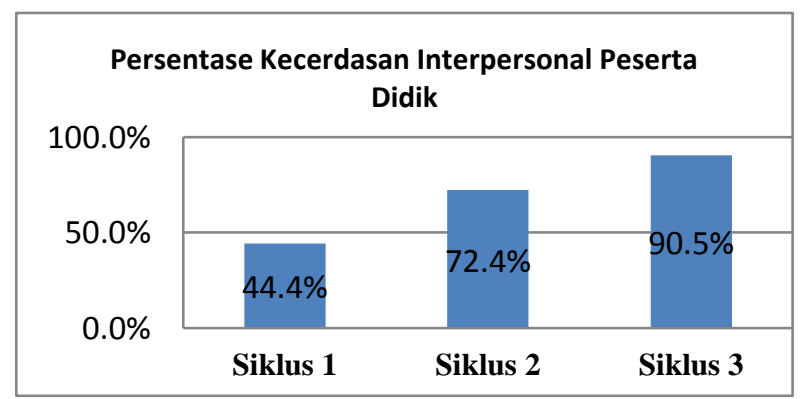

Sumber : Data diolah oleh peneliti (2017)

Third, the obstacles and solutions in applying cooperative learning model type two stay two stray (TSTS) to improve students' interpersonal intelligence on learning social studies, is first, the ability of teachers in managing time during learning activities, as in the first cycle of learning implementation exceeds the time allocation set. Where in the first cycle the bell sounded while the learning activities have not been completed. Therefore, teachers do reflection with more attention to the allocation of time when the learning process and implement learning according to scenarios that have been designed in the RPP. Secondly, the low level of interpersonal intelligence of learners in the early cycle, it can be seen in the first cycle where many protesters do not want to randomly divide the group, they tend to choose their own group of close friends. In addition, learners also can not cooperate well with one group, they more often rely on friends of one other group to do his job. To overcome this the teacher provides motivation and direction as well as around during discussion activities to monitor and guiding learners so that learners can join in collaboration with other students. Third, there are still many students who lack discipline during the learning process takes place in the early cycle, thus causing the class to be less conducive. To overcome this in the next cycle before the teacher explains the teaching materials, teachers provide guidance in the form of rules that must be obeyed learners during the learning process.

Fourth, an interpersonal intelligence of learners has increased in each cycle. This shows that cooperative learning model type two stay two stray (TSTS) can improve students interpersonal intelligence. Where the model is a model of learning with learning steps that emphasize the activities of cooperation, problem-solving, and communication among learners. In addition, this learning model also encourages learners to interact and build good relationships with learners who are aspects of interpersonal intelligence. Increasing the interpersonal intelligence of learners each cycle can be seen as follows:

Based on the diagram above, it can be seen that there is an increase in the cycle to 1 to the third cycle. In the first cycle, obtained a score of 623 of the overall score of 14404 with a percentage of $44.4 \%$ which means included in enough categories. Overall learners still can not meet the good category on every aspect of the assessment of interpersonal intelligence. This is because learners are still familiar with the learning model used by teachers, so they still often experience confusion during the learning process. Recognizing these shortcomings, teachers try to correct the deficiencies that occur the first cycle in cycle 2 by giving more explanation about the model the learning used and guiding the learners through the learning activities. In the second cycle, the interpersonal intelligence of learners increased significantly by $28 \%$ to obtain a result with a percentage of $72.4 \%$ with a score of 1,043 out of a maximum score of 1440. In this second cycle, improvement occurs in all aspects of the assessment of interpersonal intelligence. Learners have started to understand and accustomed to the model of learning used by teachers so that some learners have earned good category on aspects of assessment of interpersonal intelligence. Next, in the third cycle, the interpersonal intelligence of learners again increased by $18,1 \%$ so as to obtain results with a percentage of $90.5 \%$ with the score of 1,271 from the maximum score of 1.404. In the implementation of this third cycle, learners have been able to meet both categories on all aspects of the assessment of interpersonal intelligence. Learners can already cooperate, 
communicate effectively, have self-awareness as a member of the group and have problem-solving skills. It is also because learners are familiar and understand the learning steps of cooperative learning type two stay two stray (TSTS) model that teachers use in the learning process. Basically improving the interpersonal intelligence of learners in each cycle is in line with the understanding of learners with the model of learning cooperative learning type two stay two stray (TSTS).

\section{CONCLUTION}

The conclusion of the research entitled "Improvement of Interpersonal Intelligence of Learners through Model Cooperative Learning (Type Two Stay Stray) at IPS Learning in Class VIII-C SMP Negeri 45 Bandung is:

First, the planning of learning implementation by using cooperative learning model type two stay two stray (TSTS) as an effort to improve the interpersonal intelligence of learners in class VIII C SMP Negeri 45 Bandung is done through several steps. The planning activities undertaken are determining the Competency Standards and Basic Competencies, subject matter, making the Lesson Plans (RPP), making speaking cards and observation sheets.

Second, the implementation of learning by applying cooperative learning model type two stay two stray (TSTS) to improve the interpersonal intelligence of learners is done in three cycles with two actions/meetings in each cycle. Implementation of this action is carried out in accordance with the pre-planned implementation plan of learning, with learning activities that emphasize group discussion activities, exchanging information among learners through visiting activities and receiving guests, problem-solving and presentation. This is done to encourage students' ability to build good relationships, cooperate, solve effective problems and communicate in accordance with aspects of interpersonal intelligence through cooperative learning model type two stay

\section{REFERENSI}

Komalasari, Kokom (2013). Contextual learning. Bandung: Refika Adiatama

Sagala, Syaiful. (2011). The concept and meaning of learning. Bandung: Alfabeta

Sapriya. (2012). IPS education. Bandung: PT Young Rosdakarya

Uno, Hamzah. (2010). Manage Intelligence in Learning.

Jakarta: Earth Literacy

Gardner, Howard. (2003). Multiple Intelligence (Multiple Intelligences). Batam: Interaksara.

Safaria, T. (2005). Interpersonal Intelligence: Interpersonal Intelligence Child Development Method. Yogyakarta: Amara Books.

Majid, Abdul. (2013). Learning strategies. Bandung: PT Young Rosdakarya

Wiriatmadja, Rochiati. (2009). Class Action Research Methods. Bandung: PT. Youth Rosdakarya.

Muslich, Masnur. (2009). Implement PTK (Classroom Action Research) was easy. Malang: PT Bumi Literacy.

Huda, Miftahul. (2015). Models of Teaching and Learning. Yogyakarta: Student Library. two stray (TSTS). As for the implementation of the action in each cycle get different results and experience improvement in each cycle.

Third, the effort to overcome the obstacles that occur at the time of learning through cooperative learning model type two stay two stray (TSTS). In the implementation of the action, researchers often encounter obstacles or obstacles which occurs mainly early in the cycle. It can be seen the results of observations made by researchers with observers at the time of action. In this case, so that researchers can achieve research objectives to improve students' interpersonal intelligence, researchers do reflection to find solutions and make improvements to the shortcomings/barriers that occur in the previous cycle.

Fourth, the improvement of interpersonal intelligence of learners through cooperative learning model type two stay two stray (TSTS) of each cycle has increased significantly. This can be seen from the improvement in each aspect of the assessment of interpersonal intelligence indicators from the first cycle to the third cycle. In the first cycle, obtained a percentage score of $44.4 \%$, the second cycle experienced a significant increase of $28 \%$ to obtain a result with a percentage of $72.4 \%$. Furthermore, on the 3rd cycle, experiencing a return increase of $18.1 \%$ to obtain a result with a percentage of $90.5 \%$. In this third cycle as a whole, the learners have been able to achieve good category on every aspect of interpersonal intelligence assessment. From the data can be seen clearly that the application of cooperative learning model type two stay two stray (TSTS) can improve the interpersonal intelligence of learners.

\section{ACKNOWLEDGMENTS}

Thanks to Social Science Studies Program who have published this article.

\section{Skripsi}

Rizki Andrian. (2016). Interpersonal Intelligence Through Improved Student Learning Model Cooperative Learning Jigsaw mode on Learning IPS. (Classroom Action Research in Class VII-A SMP Negeri 3 Lembang). not published

\section{Journals}

Santoso, Sayanta. (2010). Definition, Scope and Objectives IPS. [Online] available at:https://mrcumlaude.files.wordpress.com/2010/10/ips-1paket-1.pdf

Zainuddin, (2014). Experimentation Cooperative Learning Model Two Stay Two Stray And Numbered Heads Together On Main Material Function Seen From Interpersonal Intelligence Smp Viii State Grade Se-Surakarta [online] .tersedia:http://jurnal.fkip.uns.ac.id/index.php/s2math/article/v iew/3884/2750

Wayudi, Deddy. (2011). Intelligence-Based IPS learning intrapersonal, interpersonal and Existential. [on line]. Available

in:http://jurnal.fkip.uns.ac.id/index.php/s2math/article/view/38 $84 / 2750$ 